\title{
Anatomia de estípulas e coléteres de Psychotria carthagenensis Jacq. (Rubiaceae) ${ }^{1}$
}

\author{
Narah Costa Vitarelli2,4 e Marisa Santos ${ }^{3}$
}

Recebido em 19/03/2008. Aceito em 09/12/2008

RESUMO - (Anatomia de estípulas e coléteres de Psychotria carthagenensis Jacq. (Rubiaceae)). Psychotria carthagenensis (Rubiaceae) pode ser identificada pela presença de estípulas apicais lanceoladas. Muitos gêneros da família têm estípulas com estruturas secretoras, denominadas coléteres. Sobre a estrutura de estípulas e coléteres pouco é conhecido. O objetivo do presente trabalho foi caracterizar anatomicamente estípulas e coléteres de indivíduos de P. carthagenensis ocorrentes no Estado de Santa Catarina (Brasil). Amostras de estípulas apicais dos ramos foram coletadas, fixadas e processadas para estudos em microscopias óptica e eletrônica de varredura. Testes histoquímicos foram aplicados em material in vivo. As estípulas são fundidas pela base e separadas na porção apical. Na face adaxial ocorrem tricomas multicelulares, entre os quais estão os coléteres. Estes têm base constricta, poros na superfície cuticular e epiderme em paliçada envolvendo um parênquima axial, o qual pode conter ráfides. Os coléteres secretam substâncias mucilaginosas. Esta secreção é muito importante para proteger o meristema apical caulinar e as folhas jovens.

Palavras-chave: coléteres, estípula, Psychotria carthagenensis, Rubiaceae

ABSTRACT - (Stipule and colleter anatomy of Psychotria carthagenensis Jacq. (Rubiaceae)). Psychotria carthagenensis (Rubiaceae) is identified by the presence of lanceolate apical stipules. Several Rubiaceae genera have stipules with secretory structures called colleters. Little is known about the structures of stipules and colleters. This work aimed to characterize anatomically the stipules and the colleters of Psychotria carthagenensis from Santa Catarina state (Brazil). Apical shoot stipule samples were collected, fixed, and processed for light and scanning electron microscopy studies. Histochemical tests were made on in vivo material. The bases of stipules are connected and the apices are separate. On the adaxial surface, there are multicellular trichomes and the colleters are found among these. They have a constricted base, pores on the cuticle surface, parenchymatic middle axis surrounded by a layer of palisade-like epidermal cells, in which may have raphides. The colleters secrete a mucilaginous substance that is very important to protect the apical shoot and young leaves.

Key words: colleters, stipules, Psychotria carthagenensis, Rubiaceae

\section{Introdução}

Nas Américas, a família Rubiaceae está representada por 229 gêneros e 5200 espécies (Delprete 1999), dentre elas Psychotria carthagenensis Jacq. com distribuição desde a Costa Rica até a Argentina; no Brasil ocorre do Pará ao Rio Grande do Sul (Delprete et al. 2005).

Psychotria carthagenensis é encontrada em ambientes bastante distintos (Klein et al. 2005). De acordo com estes autores, no Sul do Brasil, a espécie ocorre desde o nível do mar até $600 \mathrm{~m}$ de altitude, em três tipologias vegetacionais distintas: Floresta Ombrófila Densa, Restinga e Ambiente Reofítico, sendo possível observar grande variação morfológica entre as populações de cada uma dessas regiões.

Delprete et al. (2005) mencionam, dentre outras características usadas para identificação de $P$. carthagenensis, a presença de estípulas grandes, obtusas, membranáceas e que são completamente decíduas, estando presentes apenas nos ápices dos ramos. Pereira et al. (2006) também ressaltam que as estípulas apicais, cuja forma é lanceolada, são bem evidentes e representam um caráter taxonômico para a espécie.

Estípulas em muitas famílias de dicotiledôneas são estruturas capazes de secretar mucilagens, gomas ou resinas (Lersten 1974). Fahn (1979) relata a existência de estípulas jovens, as quais, em muitos gêneros de Rubiaceae, possuem estruturas secretores de mucilagem denominadas coléteres. Sua secreção protege os primórdios foliares contra a dessecação (Solereder, 1908).
Coléteres têm sido registrados em diversos órgãos vegetais, em várias famílias de dicotiledôneas (Thomas 1991). O sistema APG (Angiosperm Phylogeny Group 1998) inclui cinco famílias na ordem Gentianales, três delas portadoras de coléteres - Apocynaceae, Loganiaceae e Rubiaceae; o sistema APGII (2003) mantém esta organização filogenética, não referindo a presença de coléteres. Para Apocynaceae, Appezzato-da-Glória \& Estelita (2000) descrevem a presença de coléteres em cotilédones, ápices caulinares, folhas maduras e região nodal de Mandevilla illustris (Vell.) Woodson e M. velutina (Mart. ex Stadelm.) Woodson; Rio et al. (2002) referem estas estruturas em região nodal do caule de Prestonia coalita (Vell.) Woodson e Simões et al. (2006) descrevem a presença de coléteres nos cálices de sete espécies da família. Em Rubiaceae, os coléteres ocorrem quase exclusivamente na superfície adaxial ou na margem das estípulas (Lersten 1974), como, por exemplo, em Simira glaziovii (K. Schum.) Steyerm., S. pikia (K. Schum.) Steyerm. e S. rubra (Mart.) Steyerm. nas quais estão presentes na face adaxial das estípulas (Klein et al. 2004).

Ao longo da história da botânica, raras têm sido as publicações detalhando as características estruturais de estípulas e coléteres. Tais estruturas merecem mais estudos, tanto pela relevância taxonômica e filogenética para a família Rubiaceae, quanto pela possível importância para o sucesso adaptativo das espécies em seu hábitat.

Os objetivos do presente trabalho foram caracterizar anatomicamente as estípulas e os coléteres de indivíduos de

\footnotetext{
1 Parte da Dissertação de Mestrado da primeira Autora, Programa de Pós-Graduação em Biologia Vegetal da UFSC

2 Rua da Mantiqueira, 42, Bairro João Brás, 36570-000, Viçosa, MG, Brasil

3 Universidade Federal de Santa Catarina, Departamento de Botânica, 88040-900 Florianópolis, SC, Brasil

4 Autor para correspondência: narahvitarelli@yahoo.com.br
} 
Psychotria carthagenensis ocorrentes em três tipologias vegetacionais (Floresta Ombrófila Densa, Restinga e Ambiente Reofítico) no Estado de Santa Catarina (Brasil).

\section{Material e métodos}

O estudo foi realizado em três tipologias vegetacionais ocorrentes no estado de Santa Catarina (Brasil): Floresta Ombrófila Densa, Restinga e Ambiente Reofítico. Em cada uma das três tipologias vegetacionais estudadas, foram coletados ramos de três indivíduos adultos distintos, sendo analisados três ápices caulinares, contendo estípulas, por indivíduo.

Foram feitas secções transversais e longitudinais do material in vivo e fixado. Os testes histoquímicos utilizados em material in vivo, seccionado com auxílio de lâmina de barbear, foram: tionina, para detecção de mucilagem (Purvis et al. 1964 - apud Kraus \& Arduin 1997); ácidos clorídrico, sulfúrico e acético, para deteç̧ão da natureza química dos cristais (Evans 1989). As secções controle foram realizadas, simultaneamente aos testes histoquímicos, conforme procedimento padrão. Amostras fixadas em glutaraldeído 2,5\%, tamponadas com fosfato de sódio $0,1 \mathrm{M}, \mathrm{pH} 7,2$, foram desidratadas em série etílica gradual, infiltradas em hidroxietilmetacrilato e coradas com azul de toluidina (Ruzin 1999). Secções, variando de 8 a 12 $\mu \mathrm{m}$, foram feitas em micrótomo de rotação Leica - RM 2125 RT. Imagens foram capturadas em microscópio óptico Leica MPS 30 DMLS com câmara digital Sony P92. Para análise ultraestrutural as amostras fixadas e desidratadas foram imersas em HMDS (hexametildesilasane), como meio substitutivo de ponto crítico de $\mathrm{CO}_{2}$ que, pelo processo de sublimação, reduz a tensão superficial, evitando o colapso das estruturas (Bozzola \& Russel 1991). As amostras secas, aderidas sobre suportes de alumínio, com auxílio de fita de carbono dupla face, cobertas com $20 \mathrm{~nm}$ de ouro, foram analisadas e documentadas em MEV (Microscópio Eletrônico de Varredura), marca Phillips, modelo XL30. Para identificação dos elementos químicos constituintes dos cristais foi utilizado detector de raios-X de Si-Li com janela da microssonda Super Ultra Thin Window, com sistema Link-Oxford EDX, acoplado ao MEV.

\section{Resultados e discussão}

Duas estípulas revestem e protegem os primórdios foliares e o meristema apical caulinar em $P$. carthagenensis. A partir desse meristema apical desenvolvem-se novas estípulas que irão revestir os primórdios foliares subseqüentes. Estípulas jovens podem ser visualizadas internamente às estípulas maduras, quando em secções transversais do ápice caulinar, podendo assim ser observada a seqüência do desenvolvimento dessas estruturas, desde sua região basal até a apical (Fig. 1-5). Na porção basal, as estipulas encontram-se completamente fundidas formando uma estrutura única, porém com uma área mais densa, a qual apresenta uma concavidade no local onde inicia o processo de cisão (Fig. 1). Em sentido acrópeto, a face adaxial de ambas as estípulas, na área de cisão, mostram evidências de intensa atividade mitótica, com células pequenas e ordenadas, originando um bordo foliar recurvado e direcionado centrifugamente (Fig. 2). A formação histológica observada lembra o processo de abscisão foliar, descrito por Fahn (1974), porém sem suberização das paredes celulares. Na medida em que a face adaxial sofre divisões celulares, os bordos das estípulas voltados para fora se tornam mais distintos; e fileiras de células adjacentes gradualmente vão desprendendo-se (Fig. 3) até a completa separação das estípulas na porção médio-apical (Fig. 4). Portanto, secções transversais do ápice caulinar contendo estípulas maduras, ou seja, totalmente expandidas, revelam que a porção basal é fundida (Fig. 5), a porção média pode ainda estar parcialmente desprendida (Fig. 6) e a porção apical é livre (Fig. 7).

O posicionamento das estípulas em relação aos primórdios foliares remete à filotaxia oposta cruzada da família Rubiaceae (Fig. 5).

As estípulas de $P$. carthagenensis apresentam epiderme uniestratificada com tricomas unicelulares, os quais são curtos na face abaxial e longos na face adaxial (Fig 8). A presença dos tricomas curtos variou entre os indivíduos dos três ambientes estudados, estando ausentes nos indivíduos florestais. Entremeados aos longos tricomas da face adaxial ocorrem os coléteres (Fig. 8-9). Lersten (1974) descreve que tais estruturas secretoras apresentam-se quase sempre acompanhadas por tricomas multicelulares não ramificados. Em $P$. carthagenensis, os coléteres são constituídos por uma epiderme secretora em paliçada que envolve uma coluna central de células parenquimáticas alongadas (Fig. 9-10). Tais características conferem aos coléteres desta espécie a classificação como do tipo padrão (S - 'standard'), definido por Lersten (1974). Este tipo de coléter foi também encontrado em outros grupos taxonômicos a exemplo de Mandevilla Lindl. (Apocynaceae) por Appezzato-da-Glória \& Estelita (2000) e Caryocar brasiliensis Camb. (Caryocaraceae) por Paiva \& Machado (2006). A presença de uma coluna central formada por células parenquimáticas sugere que os coléteres de Psychotria carthagenensis possuam uma origem mista, a partir da protoderme e do meristema fundamental, o que permite concluir que, para esta espécie, os coléteres não devem ser considerados tricomas, como definido por Solereder (1908), Lersten \& Horner (1968) e Fahn (1979), mas sim como emergências, terminologia discutida por Rio et al. (2002) e Paiva \& Machado (2006).

Em $P$. carthagenensis, não foram observados tecidos vasculares nos coléteres; sugere-se portanto, que a condução dos elementos precursores da secreção até a epiderme secretora seja feita de célula-a-célula pelos tecidos da estípula passando pelo parênquima central do coléter. Lersten \& Horner (1968) e Paiva \& Machado (2006) esclarecem que as células centrais dos coléteres estabelecem, através de numerosos plasmodesmos, conexões simplásticas umas com as outras, especialmente nas paredes terminais, e conectam-se ao epitélio secretor por suas paredes laterais. De acordo com os autores, as células centrais podem transportar os elementos precursores da secreção até a epiderme. Em Simira glaziovii (Klein et al. 2004), Rubiaceae, foram observados traços vasculares no parênquima dessas estruturas. No entanto, a ausência de vascularização também ocorre nos coléteres de alguns gêneros da família Apocynaceae, como Mandevilla (Appezzato-da-Glória \& Estelita 2000) e Oxypetalum R. Br. (Schwarz \& Furlan 2002), bem como 

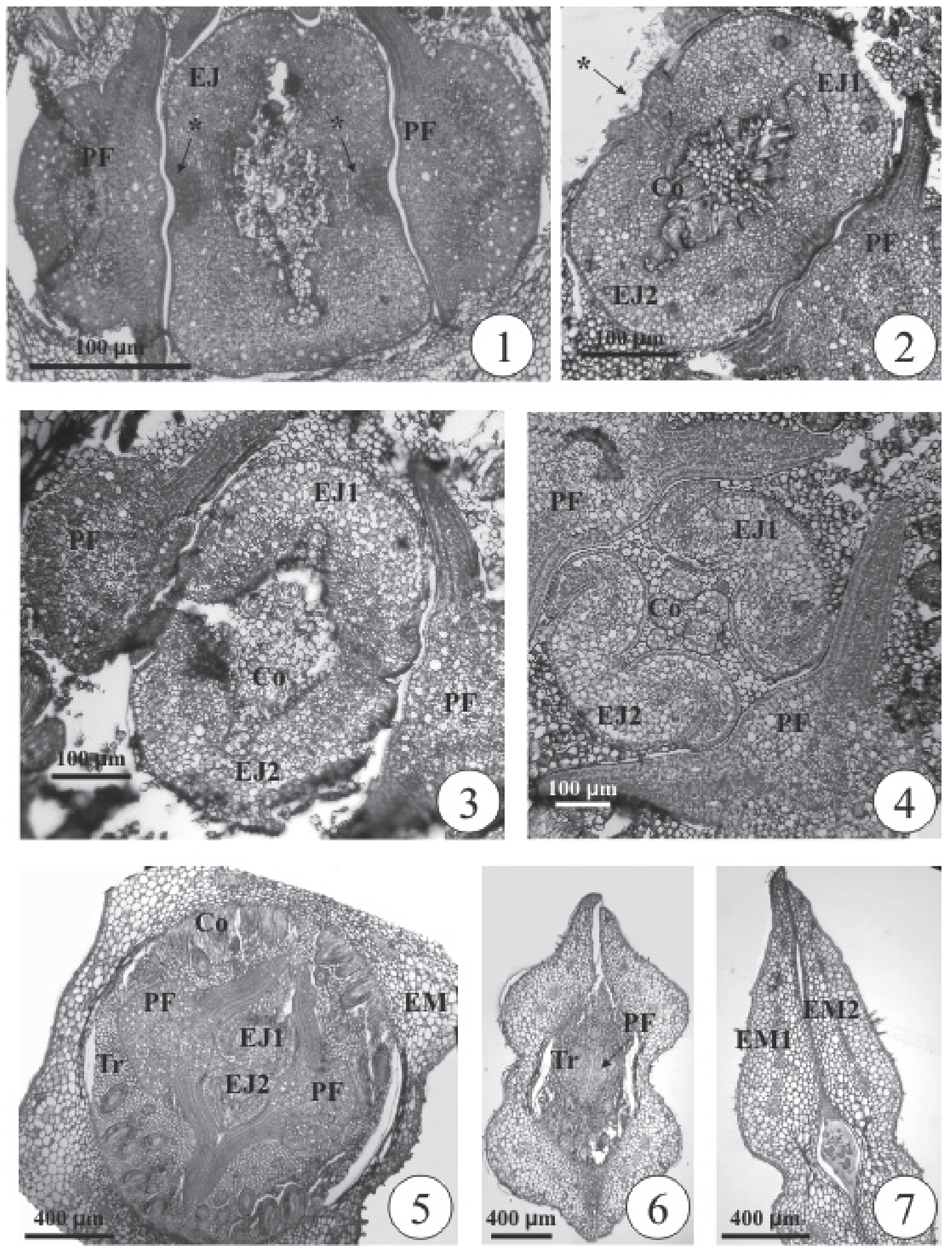

Figuras 1-7. Seccões transversais de estípulas apicais de Psychotria carthagenensis Jacq., em microscopia óptica. 1-4. Seqüência de desenvolvimento da estípula jovem em sentido acrópeto. 1. Estípula jovem completamente fundida em uma única estrutura. Seta com asterisco: região densa - área de cisão. 2. Início do processo de cisão. Seta com asterísco: início da formação dos bordos de cada estípula (EJ1 e EJ2) no ponto de cisão. 3. Separação dos tecidos das duas estípulas. 4. Estípulas completamente separadas na região médio-apical. 5-7. Seqüência de desenvolvimento da estípula madura em sentido acrópeto. 5. Porção basal da estípula madura completamente unida. 6. Porção média da estípula; estrutura em desprendimento parcial. 7. Porção apical; folhas estipulares completamente separadas. Co= Coléter; EM= Estípula madura; $\mathrm{EM} 1=$ Estípula madura 1; EM2= Estípula madura 2; EJ= Estípula jovem; EJ1= Estípula jovem 1; EJ2= Estípula jovem 2; $\mathrm{PF}=\mathrm{Primó} r d i o$ foliar; $\mathrm{Tr}=\mathrm{Tricomas}$. 

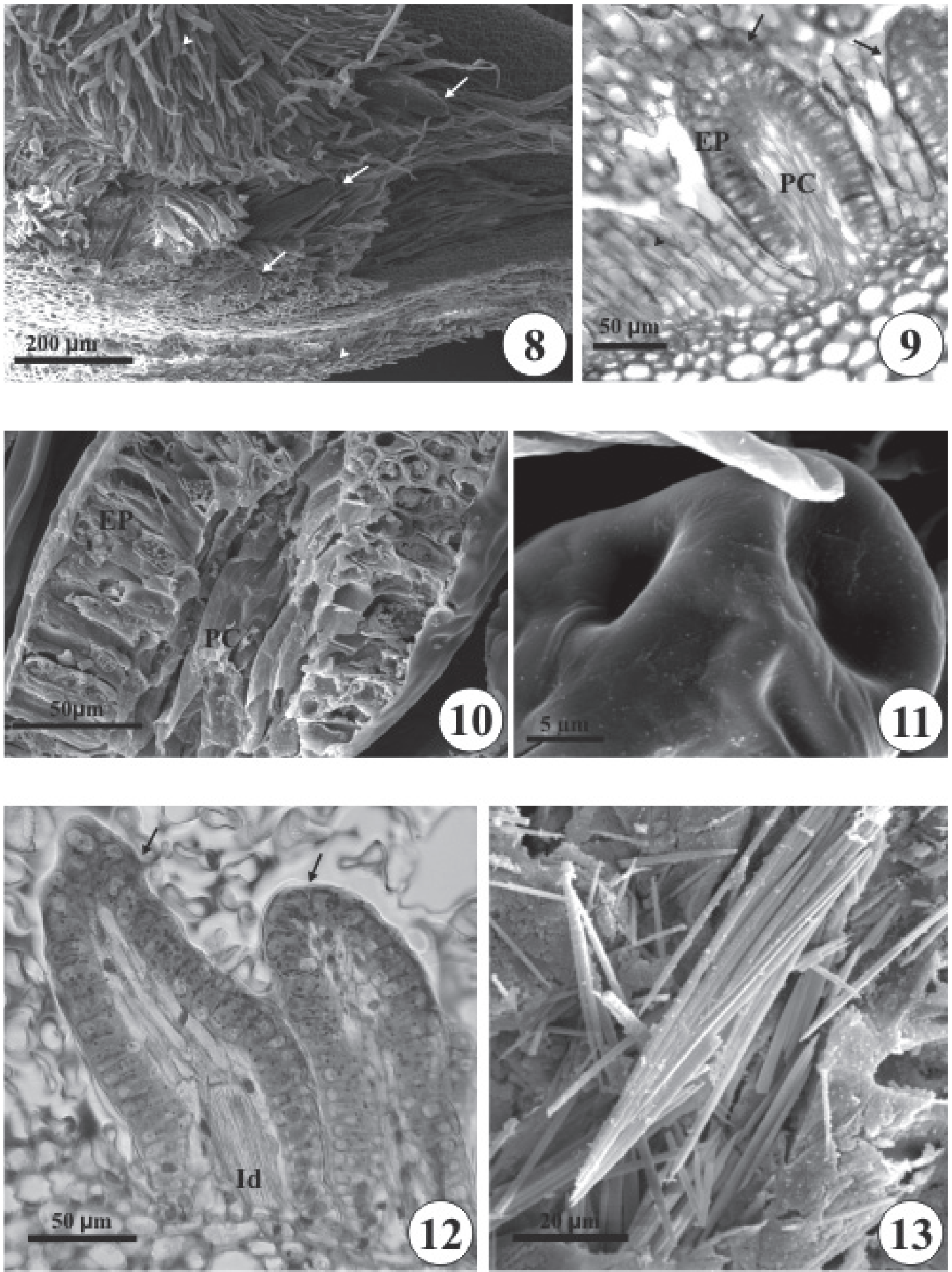

Figuras 8-13. Detalhes de estípulas e coléteres de Psychotria carthagenensis Jacq. 8. Vista geral da superfície adaxial da estípula longitudinalmente. Coléteres entremeados aos tricomas que revestem toda face interna da estípula. Uma pequena porção da face abaxial está visível e apresenta curtos tricomas unicelulares. 9. Secção transversal da estípula madura, evidenciando a estrutura geral do coléter. 10. Tecidos constituintes do coléter. 11. Superfície do coléter, evidenciando os poros na superfície cuticular. 12. Seç̧ão transversal da estípula madura evidenciando idioblastos, contendo ráfides, presentes no parênquima central do coléter. 13. Detalhe das ráfides no eixo parenquimático do coléter. 8, 10,11 e 13. microscopia eletrônica de varredura. 9 e 12. Microscopia óptica. E= Epiderme em paliçada; Id= Idioblastos; PC= Parênquima central; Seta= Indica coléteres; Cabeça de seta= indica tricomas. 
em Caryocar brasiliensis, uma Caryocaraceae (Paiva \& Machado 2006). Appezzato-da-Glória \& Estelita (2000) referem que a presença de vascularização nos coléteres está relacionada com a proximidade destas estruturas com os traços vasculares do órgão em que se encontram.

Foram observados inúmeros poros ao longo da superfície cuticular dos coléteres de P. carthagenensis (Fig. 11), através dos quais acredita-se que a secreção seja eliminada. Lersten \& Horner (1968) relatam que os tricomas secretores de $P$. bacteriophila Valeton não apresentam cutícula, fato que determina a rápida degeneração dos coléteres, por dessecação, após a expansão dos primórdios foliares que emergem no ápice das estípulas. Para estes autores, durante a secreção ativa parece haver apenas uma perda fibrilar das paredes celulares das células secretoras. Já em Caryocar brasiliensis, Paiva \& Machado (2006) não observaram poros na superfície dos coléteres, o que permitiu a esses autores concluir que a secreção se dá pela ruptura da cutícula devido à pressão da secreção que se acumula num espaço subcuticular. Cabe ressaltar que em $P$. carthagenensis não ocorre espaço subcuticular.

A análise histoquímica revelou presença de mucilagem nos coléteres de indivíduos de $P$. carthagenensis pertencentes às populações dos três ambientes estudados. A secreção de mucilagem por coléteres já foi descrita em literatura (Lersten \& Horner 1968; Lersten 1974; Fahn 1979). Solereder (1908) discute que esta mucilagem ocorre de forma tão abundante que as folhas jovens, que emergem do revestimento da estípula, ficam cobertas pela secreção, sendo esta uma proteção contra a dessecação. Tal característica é de fundamental importância para os indivíduos de $P$. carthagenensis que crescem nos ambientes reofíticos e nas restingas, onde a restrição hídrica se faz evidente, seja por períodos de baixa pluviosidade ou por alta salinidade respectivamente. Lersten \& Horner (1967) relataram a importância da secreção dos coléteres de $P$. bacteriophila para o estabelecimento de uma associação simbiótica com bactérias através da formação de nódulos foliares. De acordo com aqueles autores, a secreção proveniente dos coléteres, juntamente com as bactérias presentes no espaço formado entre as estípulas e os primórdios foliares, penetra pelo poro estomático desses primórdios iniciando a formação dos nódulos bacterianos. Em P. carthagenensis este tipo de associação não foi observada.

A presença de idioblastos contendo ráfides no parênquima axial dos coléteres foi verificada em $P$. carthagenensis (Fig. 12-13); microanálises químicas confirmaram a presença de cálcio nestes cristais. Lersten (1974) relatou que a ocorrência de cristais em coléteres é incomum, entretanto, Schwarz \& Furlan (2002) observaram idioblastos contendo drusas de oxalato de cálcio no parênquima interno dos coléteres de Oxypetalum obtusifolium Malme.

$\mathrm{Na}$ base dos coléteres de $P$. carthagenensis é possível observar uma leve constrição (Fig. 9). Situação bastante semelhante também ocorre em outras espécies de Rubiaceae, como nos coléteres de espécies de Simira Aubl., estudadas por Klein et al. (2004). A presença de pedúnculo foi relatada para Apocynaceae, em coléteres de Prestonia coalita (Rio et al. 2002), e Caryocaraceae, em Caryocar brasiliensis (Paiva \& Machado 2006).

Estudos estruturais dos coléteres podem oferecer subsídios para futuros trabalhos de taxonomia e relações filogenéticas na família Rubiaceae. A importância ecológica destas estruturas ainda está pouco esclarecida, mais estudos se fazem necessários para que se possa elucidar a função destas estruturas em relações ecológicas, como simbiose com bactérias. No entanto, a função de proteção contra a dessecação do ápice caulinar e dos primórdios foliares parece estar bem definida.

\section{Agradecimentos}

Ao professor Ademir Reis pelo auxílio durante as coletas. Ao $\mathrm{CNPq}$ pela bolsa concedida durante a realização deste trabalho.

\section{Referências bibliográficas}

Angiosperm Phylogeny Group. 1998. An ordinal classification for the families of flowering plants: APG. Annals Missouri Botanical Garden 85: 531-553.

Angiosperm Phylogeny Group. 2003. An update of the Angiosperm Phylogeny Group classification for the orders and families of the flowering plants: APGII. Botanical Journal of the Linnean Society 141: 399-436.

Appezzato-da-Glória, B. \& Estelita, M.E.M. 2000. Development, structure and distribuição of colleters in Mandevilla illustris e M. velutina (Apocynaceae). Revista Brasileira de Botânica 23: 113-120.

Bozzola, J.J. \& Russel, L.D. 1991. Electron Microscopy. Principles and Techniques for Biologists. Boston, Jones and Barlett Publichers.

Delprete, P.G. 1999. Rondeletieae (Rubiaceae). Flora Neotropica. Monograph 77. New York, The New York Botanical Garden Press Bronx.

Delprete, P.G.; Smith, L.B. \& Klein, R.M. 2005. Pp. 542-549. In: Reis, A. 2005. (ed.). Rubiaceae. I Parte - As Plantas/Monografia - Rubi, Vol. II - Gêneros de H-T. 20. Gardênia até 46. Tocoyena. Flora Ilustrada Catarinense, Itajaí.

Evans, W.C. 1989. Cell Differentiation and Ergastic Cell Contents. Pp. 3957. In: Pharmacognosy. $3^{\mathrm{a} E d}$. London, Baillière Tindall.

Fahn, A. 1974. Plant Anatomy. Madri, Ed. H. Blume.

Fahn, A. 1979. Secretory Tissues in Plants. London, Academic Press.

Klein, R.M.; Reis, A. \& Iza, O.B. 2005. Observações Ecológicas. Pp. 542-549. In: Reis, A. (Ed.). 2005. Rubiaceae. I Parte - As Plantas/ Monografia - Rubi, Vol.II, Gêneros de H-T. 20. Gardênia até 46. Tocoyena. Flora Ilustrada Catarinense, Itajaí.

Klein, D.E.; Gomes, V.M.; Silva-Neto, S.J. \& Cunha, M. 2004. The structure of colleters in several species of Simira (Rubiaceae). Annals of Botany 94: 733-740.

Kraus, J.E \& Arduin, M. 1997. Manual Básico de Métodos em Morfologia Vegetal. Seropédica, Editora Universidade Rural.

Lersten, N.R. 1974. Morphology and distribuition of Colleters and crystals in relation to the taxonomy and bacterial leaf nodule symbiosis of Psychotria (Rubiaceae). American Journal of Botany 61: 973-981.

Lersten, N.R. \& Horner, H.T.Jr. 1967. Development and structure of bacterial leaf nodules in Psychotria bacteriofila Val. (Rubiaceae). Journal of Bacteriology 94: 2027-2036.

Lersten, N.R. \& Horner, H.T.Jr. 1968. Development, structure and function of secretory trichomes in Psychotria bacteriofila (Rubiaceae). American Journal of Botany 55: 1089-1099.

Paiva, E.A.S. \& Machado, S.R. 2006. Colleters in Caryocar brasiliensis (Caryocaraceae), ontogenesis, ultraestructure and secretion. Brazilian Journal of Biology 66: 301-308. 
Pereira, Z.V.; Carvalho-Okano, R.M. \& Garcia, F.C.P. 2006. Rubiaceae Juss. Da Reserva Florestal da Mata do Paraíso, Viçosa, MG, Brasil. Acta Botanica Brasilica 20: 207-224.

Rio, M.C.S.; Castro, M. M. \& Kinoshita, L. S. 2002. Distribuição e caracterização anatômica dos coléteres foliares de Prestonia coalita (Vell.) Woodson (Apocynaceae). Revista Brasileira de Botânica 25: 339-349.

Ruzin, S.E. 1999. Plant microtechnique and microscopy. New York, Oxford University Press.

Schwarz, E.A. \& Furlan, A. 2002. Coléteres foliares de Oxypetalum R.
Br. (Asclepiadoideae, Apocynaceae) - Aspectos ultraestruturais e anatômicos úteis à taxonomia das espécies do Paraná (Brasil). Acta Biologica Paranaense 31: 79-97.

Simões, A.O.; Castro, M.M. \& Kinoshita, L.S. 2006. Calycine colleteres in seven species of Apocynaceae (Apocynoideae) from Brazil. Botanical Journal of the Linnean Society 152: 387-398.

Solereder, H. 1908. Systematic anatomy of the dicotyledons. Vol. II. Oxford, Clarendon Press.

Thomas, V. 1991. Structural, fuctional and phylogenetic aspects of the colleter. Annals of Botany 68: 287-305 